\title{
Analysis of Metal Content in Water of River Beas in Himachal Pradesh, India
}

\author{
SUMAN SHARMA ${ }^{1 *}$ and YOGESH KUMAR WALIA ${ }^{2}$ \\ ${ }^{1}$ Research Scholar, Career Point University Kota, Rajasthan - 325003, India. \\ ${ }^{2}$ Department of Chemistry, Career Point University Hamirpur, \\ Himachal Pradesh - 176041, India. \\ *Corresponding author E-mail: sumanavinasharma@gmail.com
}

http://dx.doi.org/10.13005/ojc/330161

(Received: May 02, 2016; Accepted: December 31, 2016)

\begin{abstract}
In present investigation analysis of water was done during monsoon, winter and summer seasons for metal content of river Beas in Himachal Pradesh during the year 2014-15. Metals such as Calcium (Ca), Magnesium (Mg), Potassium (K), Sodium (Na), Copper (Cu), Iron (Fe) and Lead $(\mathrm{Pb})$ were analyzed from six sampling stations i.e. Beaskund, Shamshi, Pandohdam, Dharampur, Nadaun and Pongdam in the study area. The analysis of data reveals that $\mathrm{Ca}, \mathrm{Mg}, \mathrm{K}, \mathrm{Na}, \mathrm{Cu}$ were found to be within acceptable limit prescribed by WHO, 2011 and BIS, 2012. However, Cd and Pb were found to be higher than acceptable limit prescribed by WHO, 2011 and BIS, 2012. The presence of higher concentration of heavy metals such as $\mathrm{Cd}$ and $\mathrm{Pb}$ due to their toxicity and bioaccumulation has adverse effect on the health of living beings including humans. The study indicates that water of river Beas needs constant bio monitoring.
\end{abstract}

Keywords: River Beas, water analysis, season, metal, Himachal Pradesh.

\section{INTRODUCTION}

River basins play an important role in development of human settlements. Major civilizations often appeared where fresh water was most accessible and plentiful. River basins are useful units for management of water resources (Smith and Gleick, 2012). Most of rivers of Himachal Pradesh are perennial and main rivers are the Ravi, the Chenab, the Sutlej, the Yamuna and the Beas (WCD, 2000). The Beas river originates from Beas
Kund near Rohtang pass. The river is $464 \mathrm{~km}$ long and have catchment area of $9920 \mathrm{~km}^{2}$ (Kujur, 2013). The river water quality is highly variable in nature due to environmental conditions such as basin litho logy, climate and vegetation (Ashu and Parveen, 2010 and Chauhan and Flora, 2010). The major natural sources of dissolved and soluble matter carried by river are atmospheric inputs of material, degradation of terrestrial organic matter and weathering of surface rocks (Chauhan and Sagar, 2013 and Sharma and Walia, 2016). With rapid development 
in agriculture, mining, urbanization, industrialization, hydro electrical generation, motor vehicle pollution and above all growth of population, river water contamination with hazardous waste is becoming common phenomena (Kumar, et al.2010; CPCB, 2013 and Sharma and Walia, 2015). The discharge of commercial and industrial waste water, treated and untreated domestic sewage, solid waste containing metal salts and some agricultural practices such as fertilizers and biocides create multiple environmental hazards for mankind and sustenance of aquatic life (Ritu and Manoj, 2012). Contamination of river water with toxic metals, prevent the further use water for industrial, agricultural and drinking purposes. In addition to this many ground water resources and rivers may have higher metal concentration due to geochemical origin of salts. Naturally occurring heavy metals can be present in some areas in sufficient concentration to create pollution problem. Although, trace elements are biologically beneficial in low concentrations but long term exposure to sub lethal concentration may result in adverse chronic biological effects. In recent years heavy metal concentration has increased to dangerous levels to living environment in many regions (Ong and Kamaruzzaman, 2009; Faudzi, et al.2014 and Malik, et al.2014). The pollution in river system has increased which has not only degraded the quality of water but has also affected the flora and fauna. In this context the present study was undertaken to assess the concentration of various metals in the river Beas, so that suitability of water for irrigation and drinking purpose can be ascertained.

\section{MATERIALS AND METHODS}

The present study covered about 256 $\mathrm{km}$ stretch of river Beas, extending from Beas Kund, Kullu district to Pongdam (Maharana Partap Sagar) in Kangra district of Himachal Pradesh. In order to assess the concentration of Calcium (Ca), Magnesium (Mg), Sodium (Na), Potassium (K), Cadmium (Cd), Copper (Cu), Iron ( $\mathrm{Fe})$, Lead $(\mathrm{Pb})$ content in water of river Beas, six sampling stations i.e. 1 Beaskund (SS-1), 2 Shamshi (SS-2), Pandoh Dam (SS-3), Dharampur (SS-4), Nadaun (SS-5), and Pongdam (SS-6) were selected on the basis of identified pollution problem and upon the location of point of source of waste water discharge in the selected stretch of river Beas. The water samples were collected at about $15 \mathrm{~cm}$ depth from three points, at one third. middle, two third of water across the section of river using dip and grab sampling method using pre rinsed polythene bottles. Three water samples were collected during monsoon season, post monsoon season (winter) and pre monsoon season (summer) every fifteen days in the year 2014-15. All the samples were preserved with conc. $\mathrm{HNO}_{3}(3 \mathrm{ml} / \mathrm{L})$ and conc. $\mathrm{HCl}(0.5 \mathrm{ml} / 200 \mathrm{ml})$ solution (RANKAM, RFCL) for analysis at Environtech Laboratory Mohali, Punjab, India, using standard methods (APHA/AWWA/WEF, 2012) and other methods (Maiti, 2004). Calcium and Magnesium were determined by EDTA method. Sodium and Potassium were determined using Microprocessor Flame Photometer (Environmental \& Scientific Instruments 1382). Iron was determined using Spectrophotometer (Environmental \& Scientific Instruments 2373). Cadmium, Copper and Lead were determined using Flame Atomic Absorption Spectrometry (LABINDIA AA7000), after appropriate calibration according to standard calibration procedures. All the data obtained was subjected to statistical analysis mean and standard deviation.

\section{RESULTS AND DISCUSSION}

The results of concentration of various metals recorded during present investigation with mean value and standard deviation values are presented in Table 1-4.

\section{Calcium}

The mean concentration of $\mathrm{Ca}$ in study area of river Beas was $16.69 \pm 2.64 \mathrm{mg} / \mathrm{L}$, with monsoon season recording lowest concentration of $13.03 \pm 5.92 \mathrm{mg} / \mathrm{L}$ and winter season recording highest concentration of $19.17 \pm 5.58 \mathrm{mg} / \mathrm{L}$. The mean value of calcium was within the acceptable limit of 75mg/L prescribed by BIS, 2012.

\section{Magnesium}

The mean value of $\mathrm{Mg}$ in the study area of river Beas was $4.54 \pm 0.80 \mathrm{mg} / \mathrm{L}$ and was within the acceptable limit of $30 \mathrm{mg} / \mathrm{L}$ prescribed by BIS, 2012.

\section{Potassium}

Potassium occurs widely in environment and natural water sources and is an essential 
element for human beings. The mean value of $\mathrm{K}$ in the study area of river Beas was $1.93 \pm 0.31 \mathrm{mg} / \mathrm{L}$. WHO, 2011 and BIS, 2012 has not prescribed any guideline value of $\mathrm{Mg}$.

\section{Sodium}

Sodium is found virtually in all foods and drinking water. The mean value of $\mathrm{Na}$ in the study area of river Beas was 12.44 $\pm 6.41 \mathrm{mg} / \mathrm{L}$. WHO, 2011 and BIS, 2012 has not prescribed any guideline value of $\mathrm{Na}$.

\section{Cadmium}

Cadmium is an element that occurs naturally in earth crust in the form of various organic compounds and as complexes with naturally occurring chelating agents. It is widely used in fertilizers, batteries, industry and plastics.
The pollution of water with $\mathrm{Cd}$ results from mining, application of fertilizers and tobacco products. The summer season recorded highest concentration of $0.007 \mathrm{mg} / \mathrm{L}$, whereas mean value of $\mathrm{Cd}$ in the study area of river Beas was $0.0037 \mathrm{mg} / \mathrm{L}$, which was higher than the acceptable limit of $0.003 \mathrm{mg} / \mathrm{L}$ prescribed by WHO, 2011 and BIS, 2012. Prolonged exposure to higher concentrations of $\mathrm{Cd}$ cause severe health problems as it ranks next to mercury in toxicity.

\section{Copper}

Copper is both a nutrient and drinking water contaminant. The mean value of $\mathrm{Cu}$ in the study area of river Beas was $0.0012 \mathrm{mg} / \mathrm{L}$ which was within the acceptable limit of $0.5 \mathrm{mg} / \mathrm{L}$ prescribed by BIS, 2012.

Table 1: Showing concentration of various metals during monsoon season at all the six sampling stations

\begin{tabular}{|c|c|c|c|c|c|c|c|c|c|c|c|}
\hline \multirow{2}{*}{$\begin{array}{l}\text { Sr. } \\
\text { No. }\end{array}$} & \multirow[t]{2}{*}{ Parameter } & \multirow[t]{2}{*}{ Unit } & \multicolumn{5}{|c|}{ Sampling Stations* } & \multicolumn{3}{|c|}{ Mean } & \multirow[t]{2}{*}{ S.D. } \\
\hline & & & SS-1 & SS-2 & SS-3 & SS-4 & SS-5 & SS-6 & Value & & \\
\hline 1 & Calcium & $\mathrm{mg} / \mathrm{L}$ & 2.6 & 13 & 10 & 26 & 24 & 31.7 & 17.88 & \pm & 10.11 \\
\hline 2 & Magnesium & $\mathrm{mg} / \mathrm{L}$ & 1.2 & 2.1 & 2.6 & 4.6 & 4.5 & 6.1 & 3.52 & \pm & 1.68 \\
\hline 3 & Potassium & $\mathrm{mg} / \mathrm{L}$ & 0.5 & 2.9 & 2.5 & 1.9 & 3.3 & 2.3 & 2.23 & \pm & 0.89 \\
\hline 4 & Sodium & $\mathrm{mg} / \mathrm{L}$ & 0.4 & 3.5 & 2.7 & 6.4 & 7 & 5.4 & 4.23 & \pm & 2.28 \\
\hline 5 & Cadmium & $\mathrm{mg} / \mathrm{L}$ & 0 & 0 & 0 & 0 & 0 & 0 & 0.00 & \pm & 0.00 \\
\hline 6 & Copper & $\mathrm{mg} / \mathrm{L}$ & 0 & 0.0018 & 0.0023 & 0.0011 & 0.0015 & 0.003 & 0.0016 & \pm & 0.00 \\
\hline 7 & Iron & $\mathrm{mg} / \mathrm{L}$ & 0.22 & 0.78 & 2.34 & 1.07 & 5.11 & 1.14 & 1.78 & \pm & 1.62 \\
\hline 8 & Lead & $\mathrm{mg} / \mathrm{L}$ & 0 & 0.0075 & 0.0096 & 0.0232 & 0.0565 & 0.0368 & 0.02 & \pm & 0.02 \\
\hline
\end{tabular}

Table 2: Showing concentration of various metals during post monsoon season (Winter) at all the six sampling stations

\begin{tabular}{|c|c|c|c|c|c|c|c|c|c|c|c|}
\hline \multirow{2}{*}{$\begin{array}{l}\text { Sr. } \\
\text { No. }\end{array}$} & \multirow{2}{*}{ Parameter } & \multirow[t]{2}{*}{ Unit } & \multicolumn{5}{|c|}{ Sampling Stations* } & \multirow[b]{2}{*}{ SS-6 } & \multicolumn{2}{|l|}{ Mean } & \multirow[t]{2}{*}{ S.D. } \\
\hline & & & SS-1 & SS-2 & SS-3 & SS-4 & SS-5 & & Value & & \\
\hline 1 & Calcium & $\mathrm{mg} / \mathrm{L}$ & 10 & 15 & 18 & 23 & 27 & 22 & 19.17 & \pm & 5.58 \\
\hline 2 & Magnesium & $\mathrm{mg} / \mathrm{L}$ & 3 & 4 & 4.1 & 8.9 & 7.7 & 5.1 & 5.47 & \pm & 2.12 \\
\hline 3 & Potassium & $\mathrm{mg} / \mathrm{L}$ & 0.8 & 2.1 & 2.4 & 2.6 & 2.5 & 1.9 & 2.05 & \pm & 0.61 \\
\hline 4 & Sodium & $\mathrm{mg} / \mathrm{L}$ & 1 & 3.1 & 6.5 & 61 & 39 & 8.7 & 19.88 & \pm & 22.35 \\
\hline 5 & Cadmium & $\mathrm{mg} / \mathrm{L}$ & 0.007 & 0.004 & 0.003 & 0.004 & 0.006 & 0 & 0.004 & \pm & 0.00 \\
\hline 6 & Copper & $\mathrm{mg} / \mathrm{L}$ & 0.0003 & 0.0025 & 0.0029 & 0.0018 & 0.0019 & 0.0009 & 0.0017 & \pm & 0.00 \\
\hline 7 & Iron & $\mathrm{mg} / \mathrm{L}$ & 0.3 & 0.16 & 0.23 & 0.2 & 0.7 & 0.2 & 0.30 & \pm & 0.18 \\
\hline 8 & Lead & $\mathrm{mg} / \mathrm{L}$ & 0.0395 & 0.0307 & 0.0266 & 0.0252 & 0.0355 & 0.0259 & 0.03 & \pm & 0.01 \\
\hline
\end{tabular}


Iron

Iron is one of the most abundant metals in earth's crust and is found in natural waters. It is an essential element to almost all living things, from microorganisms to human beings. The mean value of $\mathrm{Fe}$ in the study area of river Beas was $0.83 \pm 0.67$ $\mathrm{mg} / \mathrm{L}$ which was higher than the acceptable limit of $0.3 \mathrm{mg} / \mathrm{L}$ prescribed by BIS, 2012. However WHO, 2011 has not proposed any guideline value for drinking water.

\section{Lead}

Lead is most common of the heavy elements and is found in all human tissue and organs, though not needed nutritionally. Lead is used in paints solders, acid batteries and alloys. It is also used as lubricant and anti knocking agent in vehicle fuels. The continuous exposure to lead is associated with anoxia, nausea, impaired renal function and hypertension (Kaur, 2012 and Verghese, 2015). The mean value of $\mathrm{Pb}$ in the study area of river Beas was $0.02 \mathrm{mg} / \mathrm{L}$, which was higher than the acceptable limit of $0.01 \mathrm{mg} / \mathrm{L}$ prescribed by WHO, 2011 and BIS, 2012. The contamination of river water may have been due to burning of fossil fuel by vehicular traffic along the river Beas and weathering of galena rocks in the study area. The presence of higher concentration of heavy metals such as $\mathrm{Cd}$ and $\mathrm{Pb}$ due to their toxicity and bioaccumulation has adverse effect on the health of living beings including humans

Table 3: Showing concentration of various metals during pre monsoon Season (Summer) at all the six sampling stations

\begin{tabular}{|c|c|c|c|c|c|c|c|c|c|c|c|}
\hline \multirow{2}{*}{$\begin{array}{l}\text { Sr. } \\
\text { No. }\end{array}$} & \multirow{2}{*}{ Parameter } & \multirow[t]{2}{*}{ Unit } & \multicolumn{5}{|c|}{ Sampling Stations* } & \multirow[b]{2}{*}{ SS-6 } & \multicolumn{2}{|l|}{ Mean } & \multirow[t]{2}{*}{ S.D. } \\
\hline & & & SS-1 & SS-2 & SS-3 & SS-4 & SS-5 & & Value & & \\
\hline 1 & Calcium & $\mathrm{mg} / \mathrm{L}$ & 1.6 & 9.6 & 15 & 15 & 18 & 19 & 13.03 & \pm & 5.92 \\
\hline 2 & Magnesium & $\mathrm{mg} / \mathrm{L}$ & 2.3 & 1.9 & 4 & 9.8 & 3.8 & 5.9 & 4.62 & \pm & 2.66 \\
\hline 3 & Potassium & $\mathrm{mg} / \mathrm{L}$ & 0.15 & 1.3 & 1.7 & 2.6 & 3.1 & 0.2 & 1.51 & \pm & 1.11 \\
\hline 4 & Sodium & $\mathrm{mg} / \mathrm{L}$ & 5.8 & 5.7 & 3.75 & 24 & 24 & 16 & 13.22 & \pm & 9.57 \\
\hline 5 & Cadmium & $\mathrm{mg} / \mathrm{L}$ & 0.005 & 0.005 & 0.006 & 0.008 & 0.007 & 0.008 & 0.007 & \pm & 0.00 \\
\hline 6 & Copper & $\mathrm{mg} / \mathrm{L}$ & 0.0003 & 0.0005 & 0.0003 & 0.0002 & 0.0002 & 0.0002 & 0.0003 & \pm & 0.00 \\
\hline 7 & Iron & $\mathrm{mg} / \mathrm{L}$ & 0.08 & 0.91 & 0.82 & 0.21 & 0.15 & 0.31 & 0.41 & \pm & 0.33 \\
\hline 8 & Lead & $\mathrm{mg} / \mathrm{L}$ & 0.0049 & 0.0119 & 0.0098 & 0.0196 & 0.0132 & 0.0165 & 0.01 & \pm & 0.00 \\
\hline
\end{tabular}

* SS-1 Beaskund (Distt. Kulu), SS-2 Shamshi (Distt. Kulu), SS-3 Pandoh Dam (Distt. Mandi); SS-4 Dharampur (Distt. Mandi), SS-5 Nadaun (Distt. Hamirpur) SS-6 Pong Dam (Distt. Kangra)

Table 4 : Showing concentration of various metals in water of river Beas during 2014-15

\begin{tabular}{|c|c|c|c|c|c|c|c|c|c|c|}
\hline $\begin{array}{l}\text { Sr. } \\
\text { No. }\end{array}$ & Parameter & Unit & $\begin{array}{l}\text { Seaso } \\
\text { Monsoon }\end{array}$ & $\begin{array}{l}\text { n of coll } \\
\text { Winter }\end{array}$ & $\begin{array}{l}\text { lection } \\
\text { Summer }\end{array}$ & Value & Mean & S.D. & $\begin{array}{l}\mathrm{BIS}(A L)^{*} \\
(2012)\end{array}$ & $\begin{array}{c}\text { WHO(AL)* } \\
(2011)\end{array}$ \\
\hline 1 & Calcium & $\mathrm{mg} / \mathrm{L}$ & 17.88 & 19.17 & 13.03 & 16.69 & \pm & 2.64 & 75 mg/L & - \\
\hline 2 & Magnesium & $\mathrm{mg} / \mathrm{L}$ & 3.52 & 5.47 & 4.62 & 4.54 & \pm & 0.80 & 30 mg/L & - \\
\hline 3 & Potassium & $\mathrm{mg} / \mathrm{L}$ & 2.23 & 2.05 & 1.51 & 1.93 & \pm & 0.31 & - & - \\
\hline 4 & Sodium & $\mathrm{mg} / \mathrm{L}$ & 4.23 & 19.88 & 13.22 & 12.44 & \pm & 6.41 & - & - \\
\hline 5 & Cadmium & $\mathrm{mg} / \mathrm{L}$ & 0.000 & 0.004 & 0.007 & 0.0037 & \pm & 0.00 & $0.003 \mathrm{mg} / \mathrm{L}$ & $0.003 \mathrm{mg} / \mathrm{L}$ \\
\hline 6 & Copper & $\mathrm{mg} / \mathrm{L}$ & 0.0016 & 0.0017 & 0.0003 & 0.0012 & \pm & 0.00 & $0.05 \mathrm{mg} / \mathrm{L}$ & $2 \mathrm{mg} / \mathrm{L}$ \\
\hline 7 & Iron & $\mathrm{mg} / \mathrm{L}$ & 1.78 & 0.3 & 0.41 & 0.83 & \pm & 0.67 & $0.3 \mathrm{mg} / \mathrm{L}$ & - \\
\hline 8 & Lead & $\mathrm{mg} / \mathrm{L}$ & 0.02 & 0.03 & 0.01 & 0.02 & \pm & 0.01 & $0.01 \mathrm{mg} / \mathrm{L}$ & $0.01 \mathrm{mg} / \mathrm{L}$ \\
\hline
\end{tabular}

\footnotetext{
*AL-Acceptable Limit
} 
(Das and Kaur, 2001). The study indicates that water of river Beas needs constant bio monitoring and present data can be used as baseline data.

\section{ACKNOWLEDGEMENTS}

The authors are thankful to Sh. D.S. Saini, Managing Director, Dr. Adarsh Kumar, Principal Investigator, Environtech Laboratory, Mohali, Punjab India for guidance and providing necessary facilities to undertake this investigations.

\section{REFERENCES}

1. Smith J. C. and Gleick P. H. A $21^{\text {st }}$ Century U.S. Policy. Oxford University Press, New York , 2012.

2. WCD (World Commission on Dams), 2000.

3. Kujur, A., Central Ground Water Board, Ministry of Water Resources, Govt. of India, 2013.

4. Ashu, A. and Parveen, T. Biological Forum-An International J. 2010, 2 (1) 63-66.

5. Chouhan, S. and Flora, S.J.S. Arsenic and Fluoride, I. J. Exp .Bio.2010, Vol. 48,666678.

6. Chauhan, B.S. and Sagar S.K., Biological Forum-An International J.,2013,5(1),113

7. Sharma, S. and Walia, Y.K., Curr. World Environ. 2016, 11 (1), 194-203.

8. Kumar A.; Bisht B. S.; Joshi V. D.; Singh A. K. and Talwar A., J. Hum. Ecol, 2010, 32 (3):169-173.

9. $\mathrm{CPCB}$, (Central Pollution Control Board)., 2013-14, MINARAS / 35.

10. Sharma, V. and Walia, Y.K.,2015, Curr. World Environ., 2015, . 10 (3), 967-974.

11. Mahajan, R and Bali, M. I.J.E.T.A.E. 2012,.2, (9) 551-554.
12. Ong, M. C. and Kamaruzzaman, B. Y., American Journal of Applied Science. 2009, $6(7), 1418-1423$.

13. Faudzi,F.;Yunus,K.;Miskon, M.and John,A.B. Orient J Chem 2014, 30 (2)- 479-484

14. Malik, D.; Singh, S.; Thakur, J.; Singh, R .K.; Kaur, A. and Nijhawan, S. 2014, Int.J.Corr. Microbio.App.Sci,3(10),856-863.

15. APHA/AWWA/WEF. American Public Health Association, 22 ${ }^{\text {nd }}$ Ed. Washington D.C. 2012.

16. Maiti S.K. Handbook of Methods in Environmental Studies..1, Jaipur, ABD Publishers, 2004.

17. BIS (Bureau of Indian Standards), Indian Standards, Drinking Water Specifications, $2^{\text {nd }}$ Revision, IS 10500:2012.

18. WHO (World Health Organization) Guidelines for Drinking Water Quality. 3rd Edition, Geneva, 2011.

19. Kaur, S. India J Environ. Eco.2012, 3(1):149165.

20. Verghese P.S. Orient J Chem, 2015, 31(3) 1835-1839.

21. Das, B. K. and Kaur, P. Environmental Geology (USA), 2001; 40, 908-917. 